\title{
Fluorspar Deposits in
}

Western Kentucky

\section{Part 3}

Moore Hill fault system, Crittenden and Livingston Counties.

Senator-Schwenck area, Tabb fault system, Caldwell County.

GEOLOGICAL SURVEY BULLETIN $1012-E$, F

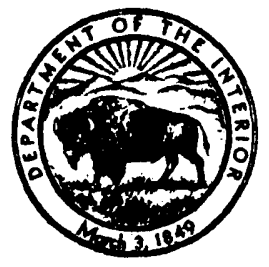





\section{Moore Hill Fault System}

Crittenden and

\section{Livingston Counties}

By WILLIAM R. THURSTON and GEORGE C. HARDIN, JR.

FLUORSPAR DEPOSITS IN WESTERN KENTUCKY

GE OLOGICALSURVEY B ULLE T I N 1012-E

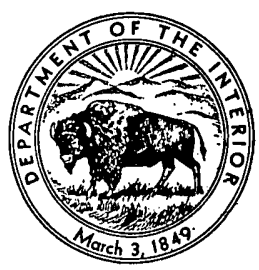





\title{
FLUORSPAR DEPOSITS IN WESTERN KENTUCKY
}

\section{MOORE HILL FAULT SYSTEM, GRITTENDEN AND LIVINGSTON GOUNTIES, KY.}

\author{
By W. R. Thurston and G. C. Hardin, JR.
}

\begin{abstract}
The Moore Hill fault system in the central part of the Kentucky-Illinois fluorspar field is about 26 miles long. Fluorspar has been produced from a part nearly 5 miles long, and since mining began in 1899 this system has yielded more than 300,000 tons of fluorspar. Lead and zinc sulfides commonly are found in the ore, but only rarely do they occur in sufficient quantity to be worth recovering.

The productive part of the fault system was mapped and the properties and principal mines described. The high-angle normal faults of the system cut limestones, sandstones, and shales of Mississippian age. Stratigraphic displacements range from less than a foot to as much as 550 feet. The fluorspar bodies are sporadically distributed in veins of calcite and fluorite along the faults.
\end{abstract}

\section{INTRODUCTION}

The Moore Hill fault system is in Crittenden and Livingston Counties, western Kentucky. The segment described in this report is $51 / 2$ to $101 / 2$ miles southwest of Marion and is reached by short gravel roads leading southwest from U. S. Highway 60 (fig. 8).

The fault system takes its name from Moore Hill, the northeastern end of a northeastward-trending flat-topped ridge. The Moore Hill fault system crosses the central part of the Kentucky fluorspar district and is one of the six most mineralized systems. This system extends from Livingston Chapel, 3 miles east of Smithland, northeastward to a place more than 5 miles northeast of Marion and has a total length of about 26 miles. Although prospect pits are scattered throughout the length of the fault system, only the $4 \frac{1}{2}$-mile segment along which fluorspar mines are located and extensions approximately a quarter of a mile both northeast and southwest were mapped and studied (see pl. 10).

Faults in the Moore Hill area were recognized in 1901 by Ulrich (1905, p. 83-85 and pl. 8). He mapped two faults; described as the Evening Star and Stevens faults. The Evening Star, Morning Star, 
and Nancy Hanks mines were located along the Evening Star fault. The Evening Star and Morning Star mines are identified with several of the old shafts on the Eagle-Cullen property, and the Nancy Hanks mine with one of the caved shafts on the Nancy Hanks property just southwest of the Salem-Dycusburg highway.

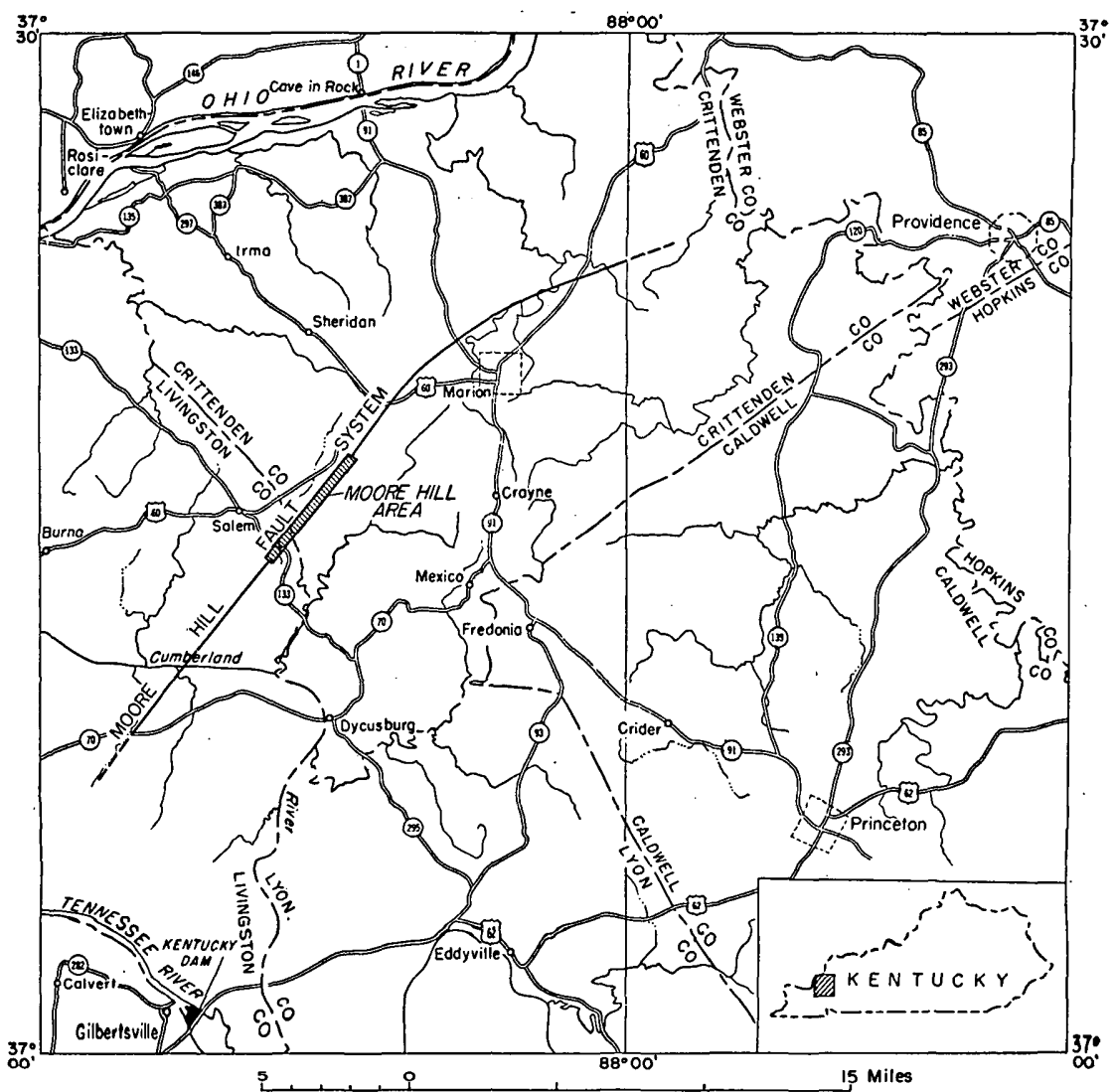

Figdne 8.-Index map of western Kentucky showing location of the Moore Hill area, Crittenden and Livingston Counties.

Currier (1923, p. 112-116) discussed the Nancy Hanks, Cullen (Evening Star), Eagle-Watson (Liberty Bond), and Two Brothers mines, but only the last two mines mentioned were accessible to him. Currier described the veins but did not attempt to interpret the stratigraphic relations.

The Cave in Rock quadrangle, in which most of the Moore Hill fault system lies, was mapped in 1920-21 by Weller (1927), who mapped the Moore Hill fault system as two subparallel faults joined by a series of cross faults. Although there is considerable difference 
in detail, the fault pattern of plate 10 of the present report corresponds in general with that shown by Weller. The writers have used the same stratigraphic divisions Weller describes in his report.

Sutton (Weller and Sutton, 1951) in 1929 studied the Eddyville quadrangle, in which the southwestern part of the Moore Hill fault system lies. The writers' interpretation of the structure and stratigraphy is essentially the same as that of Sutton.

As part of the U. S. Geological Survey's wartime investigation of strategic minerals, the part of the Moore Hill fault system known to be mineralized was" selected for detailed study and mapping to facilitate exploration for additional fluorspar resources. The present work included surface mapping on a scale of 1 inch to 100 feet (see pls. 11 and 12), detailed mine mapping, correlation of drill core and other subsurface data, and nearly continuous observations for a period of about $21 / 2$ years. Mapping of the area began in September 1942, and a short confidential preliminary report on the area around the Eagle-Watson and Davenport mines was prepared by H. E. Rothrock for use of the war agencies of the Federal Government. The surface mapping was completed in July 1944, and observations both on the surface and underground continued until March 1945. Most of the mapping was done by G. C. Hardin, Jr., W. R. Thurston, R. D. Trace, H. J. Klepser, D. A. Warner, and R. T. Russell, but some of the work was done by H. E. Rothrock, J. K. Grunig, W. H. Hass, and R. W. Lemke.

After the preliminary geologic map of the area was made available, the U. S. Bureau of Mines began core drilling in May 1943. The drilling continued intermittently until November 1944, when thirty holes had been completed. This exploration has been described in a publication by Starnes (1946).

The writers thank the mine operators for their wholehearted cooperation in permitting access to the properties and furnishing information about past mining and prospecting activities. The sources of such information are so numerous that they can not be acknowledged individually. The unpublished maps, drill logs, and reports of A. H. Reed, Sr., of Marion, Ky., were of considerable assistance, as some of the mines were inaccessible at the time of the study. The geologic maps of Stuart Weller and A. H. Sutton were especially helpful. J. S. Williams and later R. E. Van Alstine supervised the Strategic Minerals Investigation program on the Kentucky fluorspar project and, with the help of Helen Duncan and C. P. Ross, assisted the authors in collecting and compiling the data included in this report, and preparing the report for publication. 


\section{GEOLOGY}

By G. C. Hakdin, Jr.

\section{SEDIMENTARY ROCKS}

The sedimentary rocks exposed in the Moore Hill area are of Mississippian age. The section of Meramec and Chester formations that occur in the Moore Hill area and their thicknesses are as follows:

Chester group :

Thickness

Hardinsburg sandstone (partly eroded) (feet)

Golconda formation 120

Cypress sandstone $100-130$

Paint Creek shale $75-140$

Bethel sandstone

Renault formation

Meramec group :

Ste. Genevieve limestone:

Levias limestone member

Rosiclare sandstone member

Fredonia limestone member

St. Louis limestone

For general descriptions of these rocks, the reader is referred to chapter A, by James Steele Williams and Helen Duncan.

\section{MERAMEC GROUP}

ST. LOUIS LIMESTONE

The St. Louis limestone is not exposed at the surface in the Moore Hill area but has been found in many mine openings and drill holes in the area. The base of the formation in nearby areas is placed just below the lowest bed containing corals of the genus Lithostrotionella. The top generally is placed below the lowest light-gray oölite bed in the Fredonia limestone member of the Ste. Genevieve limestone. Both contacts are gradational through a distance of 15 to 30 feet, and the upper contact generally must be established on the basis of lithology.

The upper 200 feet or more of the St. Louis limestone consists of brownish-gray fine-grained limestone with large nodules and beds of blue-gray chert. This limestone commonly has conchoidal fracture and is very uniform in texture.

\section{STE. GENEVIEVE LIMESTONE}

In the Moore Hill area outcrops of the Fredonia limestone member of the Ste. Genevieve limestone, which lies above the St. Louis formation, are extensive. The broad valley northwest of the fault system is underlain by this limestone, and a sinkhole topography has been developed by solution of this rock. In the southwestern part of the 
area, the Moore Hill fault system consists of a graben flanked by two blocks of the Fredonia limestone member. This limestone is well exposed along the Salem-Dycusburg road.

The Fredonia limestone member consists of massive beds of whitishgray medium- to coarse-grained oölitic limestone with some beds of light-gray sublithographic limestone. Chert occurs in the lower beds exposed in the bluffs along Dry Creek on the Grimes property. The upper contact with the Rosiclare sandstone member in most places is sharp. In the upper part of the member, green shale beds a few inches to a few feet thick are common. It is impossible to distinguish the Fredonia from the Levias member of the Ste. Genevieve formation without finding either the intervening Rosiclare sandstone' member or a great enough thickness to preclude identification of the limestone as Levias.

In the vicinity of the Davenport mine, a shaly arenaceous limestone unit about 10 feet thick occurs in the Fredonia approximately 50 feet beneath the Rosiclare sandstone member. This unit is very similar to the sandstone below the Rosiclare (sub-Rosiclare of Weller, 1920, $\mathrm{p}$. 109) in southern Illinois and is probably correlative with it. As this. unit was not noted in any other locality in the Moore Hill area, it is: interpreted as a sandy lens occurring at this horizon.

The Rosiclare sandstone member of the Ste. Genevieve limestone: is well exposed in the northeastern part of the area on the La Rue property, where it ranges in thickness from 7 to 12 feet. This member is: poorly exposed elsewhere in the Moore Hill area but has been penetrated in many places by diamond drills. On a weathered surface, it is commonly greenish brown and is very cellular and friable because of the leaching of the calcium-carbonate cement.

In some places both the Rosiclare and Levias members probably were removed by erosion before deposition of limestone of the Renault: formation. In other places, however, only part of the Levias was removed. Locally the Rosiclare sandstone member has pinched out, however, and the Levias and Fredonia are almost indistinguishable. The contact of the Rosiclare member with the overlying Levias member commonly is gradational.

The Levias limestone member is well exposed on a hill about 500 feet northwest of the point where fault 15 (Eaton fault) leaves the mapped area (see pl. 12). It is about 30 feet thick at this locality, which is the greatest thickness of this member in the Moore Hill area. The Levias member is not well exposed elsewhere in the area but was cut by several drill holes. Part or all of the Levias commonly is absent. The contact of the Levias member with the overlying Renault formation is disconformable. 


\section{CHESTER GROUP}

Of the Chester group, only the formations from the Renault through the Hardinsburg sandstone crop out in the Moore Hill area. All the limestone formations of the Chester group are fossiliferous and may be distinguished by their faunas and to some extent by their lithologic characteristics. The sandstones are very similar, however, and generally can not be differentiated unless the overlying or underlying limestone formations can be found and identified. In several of the fault blocks in the Moore Hill area, only massive sandstone is exposed and no information about subsurface strata is available. These blocks have been referred tentatively to the sandstone formation considered most probable; on plate 11 the letter symbols are shown with a question mark. A preliminary study of the heavy accessory minerals in the Bethel and Cypress sandstones did not reveal any criteria for distinguishing these formations. The results of the study are given below.

\section{RENAULT FORMATION}

The Renault formation is exposed in only a few places in the Moore Hill area. The outcrop on the hill southeast of the Riggs shaft is the only good exposure known. The lithologic character is well known, however, from drill cores. The shale of the Renault formation commonly is thinly bedded, somewhat plastic, and contains abundant fragments of unidentifiable fossils, principally Bryozoa. The argillaceous limestone beds and beds of relatively pure limestone with shale partings become very platy upon weathering.

Although the lithologic character of the Renault is rather uniform in general, it is extremely variable in detail. Thick limestone beds become shale in a distance of as little as 200 feet.

In the Moore Hill area, the Renault formation ranges in thickness from 65 feet to 100 feet and averages about 85 feet. Much of this variation in thickness probably is due to sedimentation on the irregularly eroded surface of the Ste. Genevieve limestone, differential compaction of the more shaly phases in contrast with the more massive phases, and erosion of the top of the formation before deposition of the overlying Bethel sandstone.

The change from the limestone and shale of the Renault formation to the massive sandstone of the Bethel is commonly abrupt with no intergradation of sediments. Locally sandy limestone beds are found in the Renault but not at the top of the formation, and hence indicate a temporary influx of sand during the deposition of the Renault rather than gradation from Renault into Bethel.

BETHEL SANDSTONE

In the northeastern part of the Moore Hill area the Bethel sandstone consists entirely of sandstone, but in the central part of the 
area, in the vicinity of the Davenport mine, it contains considerable dark-gray sandy shale in the upper part. All exposures of this formation in the southwestern part of the area are massive sandstone, but the entire thickness of the formation is not exposed and no drill penetrated it. Ripple marks and crossbedding are common.

Outcrops of the Bethel sandstone are common as it is a massive bluff-forming sandstone. On a weathered surface, the rock is commonly yellow brown to red brown and generally contains small redbrown spots beneath the weathered surface. These spots are probably the result of oxidation of marcasite to limonite.

The petrography of the Bethel sandstone in segments of the drill core from U. S. Bureau of Mines holes 20 and 22 was studied. Samples were taken every 10-20 feet along the holes, which corresponds to a sample every 7-15 feet vertically. Heavy and light fractions were separated by using bromoform (specific gravity, 2.88), and the heavy fraction was divided into magnetic and nonmagnetic minerals by using a small Alnico hand magnet. Thin sections of the cores also were studied. A general description of the results of the study of these samples is given below.

The sandstone consists of fairly well-rounded quartz grains with less than 1 percent of heavy minerals. In most samples the sorting is good, but in samples of the finer grained shaly rock the grain size ranges from clay size for the argillaceous material to 0.5 millimeter for the larger sand sizes. Argillaceous material is essentially lacking in the medium-grained sandstone beds of the Bethel and the sandstone consists of interlocking quartz grains, approaching a quartzite in character. Near the Summers mine dolomite occurs as a cementing material, but sandstone with a dolomitic cement is not widespread. In some places a small quantity of calcite cements the sand grains, but for the most part the medium-grained material is poorly cemented. In the fine-grained and shaly beds, such as occur near the Davenport mine, the sandstone is made up largely of finegrained quartz particles cemented by argillaceous matter. In the more shaly parts, quartz sand is the lesser constituent.

The mineral constitutents of the sandstone are relatively uniform in the samples studied. The light mineral fractions (specific gravity less than 2.88) consisted entirely of subrounded to rounded quartz grains. There has been very little secondary enlargement of quartz grains away from the silicified zones near the faults.

Marcasite constitutes more than half of the heavy mineral fractions. The rest is made up as follows: clear zircon, 80-85 percent; brown to brownish-green tourmaline, 15-20 percent; and rare grains of sphene, apatite, rutile, and detrital fluorite. Although this petrographic study was not exhaustive, it is apparent that the great variety 
of mineral species found by Pye (1944) in his studies of this formation in the Illinois basin is not present here.

In most places the Bethel sandstone and the overlying Paint Creek shale apparently intergrade: in the northeastern part of the Moore Hill area, the base of the Paint Creek shale consists of slightly sandy shale, and near the Davenport mine where the upper part of the Bethel is quite shaly the contact between the two formations could not definitely be located. The calcareous part has been assigned to the Paint Creek shale, and the noncalcareous shale to the Bethel sandstone.

\section{PAINT CREEK SHALE}

Outcrops of the Paint Creek shale are rare in Crittenden and Livingston Counties, $\mathrm{Ky}$., as talus from the overlying Cypress sandstone commonly covers any potential exposures. Outcrops of the Paint Creek were not found in the Moore Hill area, but the formation was cut by several drill holes.

In the area northeast of the Davenport mine the locations of the contacts of the Paint Creek shale with formations above and below it are based on information from drill cores (see pl. 12). In the area southwest of the Davenport mine these contacts are based on the topographic expression and thickness of adjacent sandstone formations. The Paint Creek is characterized by its thinness and the presence of massive sandstone formations both above and below.

The contact of the Paint Creek shale with the overlying Cypress sandstone is commonly rather abrupt, but.in some places the base of the Cypress is somewhat shaly and the two formations intergrade slightly. At drill hole 22, however, a disconformity is revealed at the base of the Cypress sandstone by a conglomerate composed of shale fragments a quarter of an inch to 2 inches in diameter in a fine- to medium-grained groundmass of sandstone.

\section{CYPRESS SANDSTONE}

Exposures of the Cypress sandstone are extensive in the Moore Hill area as it is a massive bluff-forming formation. Almost the entire block between faults 1 and 3 northeast of fault 12 (pl. 12) consists of this formation. In the southwestern part of the area the Cypress is exposed at the surface between faults 1 and 2 southwest of fault 5 . In other blocks in this vicinity where the outcrops consist of massive medium-grained sandstone and no evidence is available to determine which sandstone of the Chester group is present, the formation has been tentatively designated Cypress sandstone.

The sandy shale of the Cypress sandstone generally consists of alternating bands of dark-gray shale and fine-grained gray sandstone. In places the Cypress contains as much as 25 percent of shale, but else- 
where the formation is almost entirely sandstone. The sandstone is both crossbedded and ripple marked.

On a weathered surface the massive sandstone is generally yellow brown to red brown. Beneath the surface this rock commonly shows small reddish-brown spots that are distributed throughout the body of the rock. The spots are limonitic stains probably resulting from the oxidation of marcasite in the sandstone. In unweathered specimens obtained from drill cores there are no spots.

Samples of Cypress sandstone from the drill core of U. S. Bureau of: Mines holes 20 and 22 were studied petrographically. The samples were taken every 10-15 feet along the hole, corresponding to 7-10 feet vertically, and were separated into fractions in the same way as those of the Bethel sandstone (see p. 87).

The samples of Cypress sandstone consist of fairly well sorted quartz grains with less than 1 percent of heavy accessory minerals, more than half of which is marcasite. In the finer grained samples the sorting was imperfect, however, and grain sizes range from clay size for argilJaceous material to 0.5 millimeter for the coarser size. With the exception of a small amount of silica and argillaceous material, cement in the coarser samples is almost entirely lacking, and the sandstone consists of interlocking quartz grains, approaching a quartzite in character. In the finer-grained samples, argillaceous material cements the sand grains.

The light mineral fractions of the sand (specific gravity less than 2.88) consist of rounded to subrounded quartz grains; no feldspar grains were seen in the samples studied. Away from the silicified zones near the faults secondary enlargement of the quartz grains has been slight.

About half of the heavy mineral fractions consists of magnetic minerals, chiefly marcasite. The rest is made up as follows: clear zircon, 75-85 percent; greenish-brown tourmaline, 15-20 percent; rutile, 5 percent; and rare grains of muscovite and fluorite. In comparison with the heavy minerals in samples of Bethel sandstone, the samples of Cypress sandstone contain slightly less zircon, contain as much as 5 percent rutile, and do not contain sphene and apatite. The variation in composition between samples is considerable, however; several samples were studied that contained no rutile, and the heavy minerals consisted entirely of zircon and tourmaline.

On the J. Tyner property the Cypress sandstone is only 75 feet thick, whereas northeast of the Summers mine more than 100 feet of Cypress sandstone was penetrated in drill hole 62 and the hole started in the upper part of the formation. On the J. Tyner property where the Cypress is relatively thin, it contains considerable shale; near the Summers mine, where it is much thicker, the formation is composed 296634-54-3 
almost entirely of sandstone. Some of the difference in thickness at the two localities is probably attributable to the: difference in the amount of compaction of the shale and sandstone.

The contact of the Cypress sandstone with the overlying Golconda formation is gradational wherever seen. The lower part of the Golconda consists of argillaceous limestone lenses and black shale that becomes increasingly sandy downward. The contact between the formations is drawn at the top of the highest sandstone bed, providing there are no limestone beds beneath it. If limestone beds are present beneath the sandstone bed, the contact is drawn at the base of the lowest limestone bed.

\section{GOLCONDA FORMATION}

Exposures of the Golconda formation are not extensive in the Moore Hill area, but there are several small outcrops. Massive fossiliferous limestone beds crop out on the Sisco property in the northeastern part of the area, thinly bedded limestone is exposed in the valley east of the Summers mine, and interbedded shale and fossiliferous limestone crop out in the creek east of the Pepperbox No. 1 mine. In the southwestern part of the area the Golconda formation is not exposed, but shale and limestone of the Golconda formation have been excavated from several pits. The most extensive outcrop near the Moore Hill area is on the Kirk property, southeast of the margin of the mapped area, where dark shale and impure limestone crop out for several hundred feet along a small creek.

'The massive limestore beds that crop out on the Sisco property belong to the upper part of the Golconda formation. Drill hole 68 on the J. Tyner (Eli Brown) property cut the lower 50 feet of the formation where it consists principally of dark-gray to black shale.

The contact of the Golconda formation with the overlying Hardinsburg sandstone is not exposed in the Moore Hill area. In nearby areas, however, the change from the massive dark-gray limestone of the Golconda to the massive sandstone of the Hardinsburg is abrupt.

\section{HARDINSBURG SANDSTONE}

In the Moore Hill area only the massive bluff-forming sandstones of the Hardinsburg sandstone crop out. In nearby areas, however, approximntely the lower third of the formation consists of massive sandstone, the middle third of thinly-bedded sandstone and sandy shale, and the upper third of massive saridstone with some shale beds. The sandstone and shale of this formation are distinguished from those of the Cypress and Bethel by some thin beds of limestone in the Hardinsburg.

The contact of the Hardinsburg sandstone with the overlying Glen Dean limestone was not seen in the Moore Hill area, as the Glen Dean 
limestone does not crop out. In nearby areas, however, the change from the sandstone of the Hardinsburg to the limestone of the Glen Dean is abrupt.

\section{IGNEOUS ROCKS:}

Two lamprophyre dikes are known in the Moore Hill area one occurs on the Eagle-Watson property (see pl. 12), associated with a , fluorspar vein. As the mine openings through which the vein was worked are now inaccessible, the dike could not be examined, but fit is reported to be as much as 5 feet thick.

The second lamprophyre dike is associated with fault 16 (the $\mathrm{Dike}$ fault). A vein containing principally fluorite, calcite, and 5-15 per: cent of zinc occurring as sphalerite occupies a fault that cuts across from one side of the dike to the other. Mine workings on the vem and dike were open at the time of this study, and the dike was penetrated in several places by drills. In drill cores the dike generally consists of one dike 6-10 feet thick with many associated stringers of dike material. The main body of dike rock commonly contains large slivers of marbleized limestone. The limestone country rack cut by the dike generally is recrystallized for as much as 30 feet on either side of the dike.

The dike rock is dark gray to black, fine-grained, highly altered, and contains conspicuous black to golden-brown biotite in relativefy fresh clusters as much as half an inch in diameter. Many of the biotite clusters are fractured, and the fractures are filled with minerals, probably zeolites. Under the microscope thin sections show that the rock consists largely of calcite, biotite (which constitutes 15 to 20 percent of the rock), and several small clusters of a highly altered dark mineral, probably pyroxene. Considerable quantities of chlorite and some serpentine occur chiefly as fringes around the biotite; small grains of magnetite are abundant.

\section{STRUCTURE}

$\therefore ! n$

The Moore Hill fault system is about 26 miles long and is one of the longest in the Kentucky district (Weller and Sutton, 1951). The area described in this report constitutes a complexly faulted area covering approximately 5 miles along the fault system. In the area mapped the system consists chiefly of two subparallel faults connected by a series of shorter subparallel and cross faults (see pls. 11 and 12 ). In the northeastern part of the area, the major faults are step faults downthrown to the southeast, but in the southwestern part of the area the direction of movement on the southeastern fault (fault 3 ) was reversed; the block between the faults was dropped and formed a graben about 600 feet wide. 
Faults 1 and 3 correspond to Weller's Moore Hill faults 71 and 724 respectively (Weller, 1927, p. 104). The distance between the faults ranges from 250 feet to 1,200 feet and averages about 600 feet. Both faults are sinuous, but the general strike of each is essentially N: $40^{\circ} \mathrm{E}$.

Fault 1 is the footwall fault of the system and lies between Ste. Genevieve limestone on the northwest and various formations of the lower and middle Chester group on the southeast. The stratigraphic displacement ranges from a minimum of about 150 feet on the Sisco property near the northeastern end of the area to a maximum of about 550 feet at a place between the F. Tyner and Grimes properties. In the area southwest of the Grimes property, the stratigraphic displacement ranges from 200 to 300 feet. The downthrow is to the southeast throughout the length of the fault. Fault 1 ranges in dip from $70^{\circ}$ SE. to vertical and locally dips northwest. In general, the dip averages $80^{\circ}-85^{\circ}$. SE.

Fault 1 is located definitely throughout much of the area by mine workings, drill cores, or residual boulders of slickensided quartzite, although the fault plane does not crop out. Most of the fluorspar produced from the Moore Hill fault system has come from fault 1 or from small associated faults that split from fault 1 and die out in either the hanging wall or the footwall. The main mine workings on the Nancy Hanks, Davenport, Eagle-Watson, Eagle-Cullen, and Summers properties are on fault 1.

On the Eagle-Watson property fault 1 turns rather abruptly to the exst:." In the area northeast of this change in strilee, the country rock is. very fractured, and much of the fluorspar from the Eagle-Watson property has come from these fractures. Slickensides indicate that there has been a small amount of displacement along some of the fractures, but the maximum displacement probably does not exceed 10 feet. Weller (1927, p. 104) shows the Salem fault joining the Moore Hill fault in this strongly fractured area. The Salem fault does not crop out in the area but may be projected from exposures about 1 mile west of it, where fluorspar has been mined from a small shaft sunk on the Salem fault.

On the Stevens property near the Livingston-Crittenden County line, a considerable amount of fire clay or fire sand was mined from fault 1. This material was high in silica and low in alumina (Fohs, 1905, p. 131-135). A tunnel was driven into the hill, and a drift was driven along the fault zone; clay, 20 to 35 feet wide, was mined throughout a vertical extent of about 90 feet. This clay apparently was weathered fault gouge associated with fault 1.

Several small faults diverge from fault 1 and die out in the Ste. Genevieve limestone of the footwall. Faults $1 A$ and $1 B$ are faults of this type and are known only from mine workings. 
Fault 2 lies between faults 1 and 3 and is essentially parallel to thern! It continues southwest from the mapped area but to the northeẩst is cut off by fault 5 on the Grimes property. Fault 6 may be a continuation of fault 2. The presence of this fault on the Bennett and Nancy Hanks properties is indicated by large slickensided sandstone boulders: and by material thrown out from shallow pits. On the Eagle-Cullen property this fault was explored by three pits and a shallow shaft, and was penetrated by Eagle Fluor Spar Co. in hole 9 and possibly by drill hole 4. A calcite vein in fault 2 is exposed in the northeastern-' most shallow shaft. Abundant boulders of brecciated sandstone indicate the location of the fault near its junction with fault 5 .

Fault 3, the hanging-wall fault of the system, is subparallel to fault 1 and extends through the mapped area. The sedimentary rocks in the block southeast of fault 3 are approximately horizontal. North east of the Wring and Kirk properties the southeast side of the fault is downthrown, but southwest of these properties the northwest side $e^{\circ}$ of the fault is downthrown. The maximum dislocation observed is on the Sisco property near the northeastern end of the area, where the stratigraphic displacement is approximately 250 feet.

Fault 3 has not been explored by mine workings and has been cut by only one drill hole (Riggs No. 1); however, numerous outcrops of' fault breccia and the fault plane and the presence of large boulders of brecciated and silicified sandstone mark the trace of the fault. In the mapped area southwest of Dry Creek the fault is not exposed, but it: is exposed a few hundred feet beyond the southwest margin of the mapped area. Northeast of Dry Creek on the Eagle-Cullen property, the fault trace is marked by large boulders of slickensided sandstone between an outcrop of massive Cypress sandstone on the northwest' and one of Ste. Genevieve limestone on the southeast. "Farther northeast in Rocky Branch, fault 3 is not exposed, but the strongly drag: folded and brecciated sandstone beds of the northwest wall are well exposed in a broken zone more than 100 feet wide. On the Kirk property several small pits have been sunk very near fault 3 , and brecciated sandstone has been excavated. On the southeast side of the large hill on the J. Tyner and F. Tyner properties, the fault is exposed inter:mittently for several hundred feet and several small pits have been sunk on or near it. Near the Two Brothers mine the fault was exposed in the Flannery shaft. The fault plane is best exposed at the line between the Ludwig and Eagle-Watson properties, where it djps' approximately $85^{\circ} \mathrm{SE}$. The slickensided footwall of the Cypress sandstone is exposed in a small pit, and hanging-wall material from the Hardinsburg sandstone and the Golconda formation are on the dump.

Fault breccia near fault 3 is exposed in the gully on the Ludwig property and in the road parallel to the Oxley-McCune property line. 
In the small creek on the Oxley property shale and limestone of the Golconda formation on the hanging-wall (southeast) side of the fault are well exposed. Steeply dipping sandstone beds indicate the approximate location of the fault in the gully northeast of the Summers mine. On the Sisco property several shallow pits have been sunk on faplt 3 ; drill hole 1 probably penetrated the fault.

Malt 4 leaves fault 1 near the Mosier shaft on the Grimes property, cuts diagonaly across the fault block southeast of fault 1 , and joins fault 3 on the $\int$. Tyner property. Fault 4 is exposed in the small gully epst of the Mosier shaft and on the hill southwest of Rocky Branch. It is well exposed near the road northeast of Rocky Branch, where the fault plane dips approximately $70^{\circ} \mathrm{NW}$. Several shallow pits have exposed the Cypress(?) sandstone of the footwall, and shale and limestone of the Golconda formation have been excavated from a shallow shaft in the hanging wall. On the Carrie Butler property near the junction of faults 4 and 7 , slickensided sandstones are on the dump from a shallow shaft. On the Kirk property abundant boulders of brecciated sandstone mark the trend of the fault. On the J. Tyner property fault breccia forms small exposures; two shallow shafts have been sunk in the hanging wall, and crosscuts have been driven to the fault? As exposures northeast of this property are lacking, fault 4 has been projected to a supposed junction with fault 3 .

Fault 5, a short cross fault connecting faults 3 and 4, is exposed in the southwest bank of Rocky Branch. Slickensided silicified sandstone is present throughout its entire length. The area in the vicinity of fault 5 is one of the most strongly faulted localities in the entire Moore Hill area, and faults other than those mapped probably are present.

Fault 6 , a short fault extending northeasterly between faults 5 and 4 . may be part of fault 2 offset by fault 5 . Outcrops of brecciated sandstone form a small ridge parallel to fault 6 .

Fault 7, connecting faults 1 and 4 , is well exposed in the road leiding southeast from Tyner Chapel, where steeply dipping sandstone crops out in a road cut. Throughout most of its length, the trace of the fault is marked by abundant boulders of brecciated and siticified sandstone. The fault crops out on the Eagle-Lowery property; the dip could not be measured but was found to be approximately vertical. The amount of stratigraphic displacement along fault 7 is not definitely known but is probably about 200 feet.

Fault 8 is a short fault that is not exposed on the surface. The stilike is not known, as the fault is known only from drill hole 73 .

Fault 9 is marked on the Wring property by a rather sharp hil] with small outcrops of brecciated sandstone and with abundant boulders of slickensided sandstone. This fault is well exposed south- 
west of the woods road almost parallel to the J. Tyner-Kirk property line. Northeast of this place the trace of the fault is indicated by small outcrops and abundant boulders of slickensided sandstone.

Fault 10 does not crop out, but it is well known from mine workings and drill holes on the Davenport property. In the mine workings the fault dips $55^{\circ}-60^{\circ} \mathrm{NW}$. and contains a thick fluorspar vein. Information from drill holes 80 and 83 , however, indicates that the fault becomes more nearly vertical to the southwest. The beds in the fault block bounded by faults $1,4,9,10$, and 11 dip southwest. In the vicinity of the Davenport mine the dip is approximately $15^{\circ}$, but to the southwest it flattens to approximately $5^{\circ}$. The displacement along fault 10 ranges from less than a foot on the Eagle-Watson property to approximately 300 feet on the J. Tyner (Eli Brown) property at the junction with fault 4.

Faults 11 and $11 A$ are known only from workings at the Davenport mine, where considerable fluorspar has been mined from them. These faults are essentially vertical. The stratigraphic displacement ranges from less than a foot to 150 feet on fault 11 and is about 120 feet on fault $11 A$.

Fault 12, locally called the Watson fault, connects faults 1 and 3. Sandstone beds with many highly contorted drag folds mark the trace of this fault in the vicinity of the Two Brothers mine. It is well exposed in the mine workings, and considerable fluorspar has been mined along it. Fault 12 is reported to consist of 2 parallel fractures, 10-20 feet apart in the vicinity of the Two Brothers shaft; fluorspar was mined from both of them. The fault is essentially vertical but in places dips steeply to the southeast. Fault 12 was penetrated by drill hole 47 on the Ludwig property, where it contained several feet of calcite.

Faults $12 A$ and $12 B$ have small displacements. Their presence is indicated chiefly by small outcrops of brecciated sandstone. Fault $12 A$ was cut by a horizontal drill hole from the bottom of the EagleWatson shaft.

Fault 13, a small fault similar to fault 10, is exposed in the road parallel to the Oxley-McCune property line. The fault plane is well exposed in the caved Oxley shaft and was penetrated by drill hole 61 . Fault 13 dips $60^{\circ}-70^{\circ} \mathrm{NW}$. The displacement is approximately 75 feet, with the downthrown side to the northwest.

Fault 14 is a small fault exposed in a gully between faults 1 and 3. From drill-hole information it is calculated that the southern side is downthrown approximately 30 feet.

Fault 15, the Eaton fault, is a fault cutting the Ste. Genevieve limestone. The movement along this fault was largely horizontal. The fault does not crop out in the Moore Hill area but has been pro- 
jected from mine workings less than 100 feet northwest of the' mapped area.

Fault 16, the Dike fault, is a fault of relatively small displacement; the southwest side is downthrown approximately 10 feet (see pl. 16).. The fault follows longitudinal planes of weakness in a lamprophyre dike and commonly cuts across from one side of the dike to the other. As the relation of the faulted lamprophyre dike to faults 1 and 3 is not known, the intersection of the dike with these faults is shown on plate 12 with question marks. The presence of biotite in the soil on the southeast side of fault 3, however, is taken to indicate that the dike is present southeast of these faults.

Fault 17 is a relatively low angle fault, similar to fault 10. It is known from workings in the Summers mine, and some fluorspar has been produced from it. The displacement along fault 17 is about 20 feet, and the downthrown side is on the northwest.

\section{FLUORSPAR DEPOSITS}

BY W. R. Thurston

\section{MINERALOGY}

The principal vein minerals are calcite and fluorite, and sphalerite and galena commonly are present in small quantities. The calcite generally is milky white; the fluorite ranges from white or colorless to purple and brown. Both minerals form veins in the faults, veinlets in the wall rock, and cement in fault breccia. In some places the veins are composed almost exclusively of either fluorite or calcite; in other places coarse intergrowths of these minerals are as much as 10 feet wide in the veins. Some parts of the veins are rudely banded, where fluorite as much as 3 feet wide borders 1 - to 8-foot bands of calcite or intergrown calcite and fluorite. In the minable deposits most of the fluorite is pale ; fluorite in minute veinlets in isolated exposures generally is dark purple. This generalization about the distribution of fluorite of different color, however, is not a guide to exploration or a criterion of evaluation, because thin veinlets of dark purple fluorite are common in the wall rock and fault breccia associated with commercial deposits, and veinlets of dark purple fluorite even traverse masses of the pale fluorite.

The galena (lead sulfide) and sphalerite (zinc sulfide) commonly occur as minute grains and small aggregates of grains disseminated in the fluorspar and wall rock. In a few places large masses of galena have been found in streaks within the fluorspar or calcite and accentuate the banding of a deposit. The galena is typically lead gray and has cubic crystal faces and cleavage surfaces. The sphalerite is reddish brown and massive in structure. 


\section{STRUCTURAT ENVIRONMENT}

Most of the fluorspar produced in the Moore Hill area has been mined from fault 1 and subsidiary fissures and breccia zones. Some cross faults between fault 1 and fault 3 have yielded fluorspar in commercial quantities, but fault 3 , the southeast marginal fault, has not been the site of a mining venture. More of the faults in the mapped area may be fluorspar-bearing, and other parts of the Moore Hill system may be mineralized.

Most of the fluorspar bodies occupy nearly vertical normal faults that have displacements ranging from a few feet to about 200 feet. Forr most of the known strike length, fault 1 dips southeast at an angle greater than $80^{\circ}$, but near the Pepperbox No. 1 mine a dip of $70^{\circ}$ was recorded. A few faults dip consistently at angles less than $70^{\circ}$; for example; one found underground at the Summers mine dips $45^{\circ} \mathrm{N}$., and another at the Davenport mine dips $55^{\circ} \mathrm{NW}$.

The faults generally are not exposed at the surface. The presence of a few is suggested by outcrops of silicified sandstone, but the great majority are located by indirect geologic evidence. Details of dip, width of fault zone, and some other features are accessible only in underground workings. A fault shown on the maps (pls. 10,11, and 12 ) is the trace of a median plane within the fault zone; the line drawn is invariably much narrower than the fault zone where known. Mineralization may have occurred anywhere within the fault zone; hence fluorspar bodies need not lie directly below the place indicated on the map by the fault symbol.

Fault zones range in width from less than an inch to 30 feet and pinch and swell abruptly. The zones consist of brecciated country rock, clay, and some vein filling. Slablike masses of rock bounded by fracture planes are present in many places within the fault zones. Marginal areas of brecciation and fissuring grade outward into unbroken country rock; this gradational zone may be from 50 to 150 feet wide. Fissures and small faults diverge from the larger faults. The fault zones vary in dip within short distances. Within the limits of a single fluorspar body the walls may dip steeply in one direction, become vertical, and then dip steeply in the opposite direction.

Although minable bodies of fluorspar have been found at the intersections of faults, all fault intersections have not been productive. Where wide areas of breccia have been formed at intersections, the total amount of space available for mineralization may have been great but so distributed as to have precluded the deposition of an ore body. Where faults join in an area of argillaceous rocks, the excessive fault gouge produced by deformation may have effectively sealed the channels for mineralizing solutions. Although no statistical analysis has been made of the occurrence of fluorspar deposits at fault intersec296634-54-4 
tions, the intersections are not regarded as more favorable sites for commercial bodies than the rest of the fault.

The fluorspar-bearing potentialities of a fault do not increase in proportion to the magnitude of displacement along it, as displacements along fluorspar-bearing structures are more commonly small than great. Displacement along the Moore Hill fault system ranges from a few feet to about 550 feet. Faults with movements in excess of 1,000 feet generally have been found to be barren in the KentuckyIllinois field. Extreme dislocation may produce excessive breccia and fault gouge, which do not favor the formation of the ore bodies.

\section{STRATIGRAPHIC ENVIRONMENT}

Most of the fluorspar produced from the faults of the Moore Hill system was mined from deposits that have at least one, and in many places both, of the vein walls composed of the thick massive limestones of the Meramec group. The footwall of fault 1 is made up of limestones of the Meramec group. The hanging wall of most of the fault blocks is composed of lower Chester formations, and the Meramec limestones are 75 to 300 feet beneath the surface. This relationship of fluorspar deposits to the type of country rock may be the result of fluorine-bearing solutions reacting with these relatively pure and permeable limestones. The low shale content of such limestones minimizes the amount of clay gouge available for sealing the fault zones and preventing mineralization. Undoubtedly a fault fractures massive limestones 700 feet thick differently than a section of alternating sandstones and limestones containing variable, but generally large, quantities of shale. Data at hand are not sufficient, however, to show what part the breakage characteristics of the country rock played in the localization of fluorspar.

If stratigraphic environment plays a controlling role in localizing fluorspar deposits, as suggested above, the most favorable horizons along fault 3 and many of the cross faults lie at depths ranging from 100 to 500 feet below the surface.

\section{SIZE AND ORIGTN}

Commercial bodies of fluorspar in the veins of the Moore Hill fault system have a wide variety of dimensions. Lengths are from 15 to 500 feet, heights from 12 to 275 feet, and widths from $21 / 2$ to 23 feet. A typical deposit is about 250 feet long, 200 feet high, and 4 to 6 feet wide.

Fluorite and calcite with minor amounts of sphalerite and galena were introduced by hydrothermal solutions. The minerals were deposited as fillings in the fissures and in the interstices of breccia, and also replaced brecciated material in the vein walls and within the 
veins. Exploratory work rarely fails to find calcite and traces of orte or more of the other vein minerals in the faults, but minable bodies: of fluorspar are not so common.

In some places where veins occurring in a fault contained appreciable quantities of fluorspar, rich deposits of residual fluorspar accumu* lated as a result of weathering in the humid climate. Brecciated cal:careous wall rocks and the vein calcite were readily decomposed and removed, leaving the relatively insoluble fluorspar concentrated in the overburden. Fluorspar is brittle and readily cleavable, however, and disintegrates mechanically into the gravel-spar deposits commonly found near productive fault zones. In many places these gravel-spar deposits are much wider than the vein deposits in the bedrock, owing to accumulation and lateral spreading as the surface of the zone of weathering was lowered: The weathering proceeded to great depthis along some of the faults. Some gravel-spar deposits extend to depthis of as much as 250 feet, as at the Nancy Hanks mine near the south end of the area mapped. It is not unusual for the vein to be decomposed to greater depths than the bordering wall rock.

A residual concentrate of workable gravel spar may be formed even though the fluorspar content of some veins before weathering may have been too low to be economically minable. A few places are known where a gravel-spar deposit was mined profitably to bedrocki, but the unweathered fluorspar vein below was not commercially minable.

\section{MINING AND MILLING}

The majority of shafts and pits are excavated direetly on the vein, but the larger and deeper shafts are sunk in the wall rock and' cresscuts are driven to the vein. Vein deposits are mined by open stoping or a modified shrinkage stoping. The unconsolidated gravel spar is mined by underhand stoping, benching, and top slicing.

Watercourses, ranging from small fissures a few inches wide to irregular openings 4 feet by 10 feet, developed along joints in the country rock. Locally the watercourses intersect the veins and follow them for short distances, although the faults generally are not good channels. The decomposition of the vein material and the deposition of sand and silt make troublesome "soft spots" in the vein, but do not constitute major mining problems.

Almost all ore is run through a log washer to remove clay;; sand, and silt. The ore from gravel-spar deposits generally requires no further treatment; high-grade lump fluorspar is hand sorted for shipment as acid-grade concentrate, and the finer material is generally suitable for shipment as metallurgical-grade fluorspar. Siliceous concentrates sometimes are blended with calcareous concentrates to reduce the content of objectionable impurity. Fluorspar mined from veins gen- 
erally is ground, sized, and jigged after washing. In some mills small tonnages of sphalerite and galena are recovered either in jigs or on tables. The jigged product invariably is a metallurgical-grade concentrate. The tonnage of acid-grade fluorspar obtained by hand picking is small. Milling by flotation methods is not employed at any of the properties along the Moore Hill fault system.

; The fluorspar concentrates are hauled by truck to Marion, Ky., the nearest' shipping point on the Illinois Central Railroad, or to the Cumberland River for shipment by barge. The longest haul is from the Nancy Hanks mine to Marion, a distance of $121 / 2$ miles.

\section{INDIVIDUAL PROPERTIES}

The following comments on the geologic conditions and the mining and prospecting operations at individual properties are based on direct observation wherever possible. Only a few of the workings made before 1940 are still accessible, however, and some of them made when the Moore Hill fault system was first being explored around 1900 could not be identified.

- As some of the records made available by individuals in the district were based on hearsay information even at the time they were made, it is now impossible in many cases to distinguish measurement from approximation. Some of the descriptions given are a compromise of the divergent views available, and therefore agree with no single informant. Details of dates, depths, and tonnages are subject to error, but the general picture of the past activity, despite small inaccuracies, is considered fair and reasonable because it fits so well with what can be observed at the present time.

The most important centers of production have been the Nancy Taṇks, Eagle-Watson, and Davenport properties. The H. Watson and Summers properties made important contributions to the early Auorspar production.

The Eagle-Cullen, F. Tyner, and parts of the McCune and Oxley properties have been explored extensively. The rest of the propertres have received only shallow and scattered prospecting.

* The properties are described in order from southwest to northeast along the fault system.

\section{BENNETT}

The Bennett property, owned by the heirs of Bennett and leased by Shelby, covers the southwest extension of fault 1 from the Nancy Hanks property and a small section of fault 2. The first exploratory work on the Bennett property was done in 1926 by Roberts. A shaft, shown as the Shelby shaft, was sunk on fault 1 about 1,450 feet southwest of the Nancy Hanks mine. A body of fluorspar 50 feet long was mined to a depth of 150 feet and yielded about 2,000 tons of marketatble concentrate. In about 1930 the contractors who succeeded 
Roberts sank a shaft about 300 feet farther southwest and found a small amount of zinc-carbonate ore.

In 1937 C. B. Reed drilled about 50 vertical holes along the faults on the Bennett property. The drilling indicated that fluorspar was present in some places, but the results did not encourage the esta. lishment of a mining operation here. Other lessees and contractorst have prospected along fault 1 without notable success. Some fluorspar was produced from two additional shafts sunk by the Dover Fluorspar Co. and Hershel Wring in 1942 and 1943 and by Hershel Wring in 1946, but the tonnage was not large.

\section{TEER}

The Teer property, reported to be owned by the Bennett heirs, has been prospected by a few pits. Neither fault 2 nor fault 3 , both :of which cross the property, has been extensively explored, however.

\section{NANCY HANKS}

Contractors and sublessees have mined gravel spar along fault $1^{\text {t }}$ from time to time and have found it profitable to reopen the same $\mathrm{e}^{\mathrm{i}}$ grround several times. Only the best and most accessible fluorspar has been removed. Over a strike length of about 1,200 feet most of the gravel spar has been mined to a depth of 200 feet. The total fluorspar production from the Nancy Hanks property is estimated at, 100,000 tons.

The Nancy Hanks property, owned by the heirs of H. E. Croftt and operated by W. V. Haynes, Jr., was first explored in 1900. The American Lead, Zinc, and Fluorspar Co., directed by Sylvan Price, leased the property from 1900 to 1925 . This company was in active operation from 1900 to 1908 and did the initial development work'. The Albany Mining Investment Co. obtained a sublease on the prop-: erty in 1908 and sank a shaft to a vertical depth of 330 feet, shown on' plate 11 as "Old shaft". The shaft was sunk partly in the footwall" of fault 1 and partly in the fault zone (see pl. 13), and had levels att depths of 170, 190, 230, 270, and 310 feet. These workings extended about 500 feet along the strike of the fault. The Albany Mining Investment Co. ceased operations in 1911.

The American Lead, Zinc, and Fluorspar Co. later divided the' Nancy Hanks property into three parts. The southwestern unit was leased to D. Sorey of Fredonia, Ky., who sank a shaft in 1916 but did not produce any fluorspar. The central unit was leased to Crider: \& Meyer, who mined in the area near the 330 -foot shaft, or. "Old shaft..": The northeastern unit, extending from the west tributary of the branch of Dry Creek to the Eagle-Cullen property line, yielded: a small tonnage of fluorspar from the shaft nearest: the Salem-1 Dycusburg road. By 1918 all this work had ceased. 
In 1925 W. V. Haynes, Sr., started operating the Nancy Hanks property. The present Main shaft was sunk in the footwall of fault 1. to a depth of 250 feet, and most of the gravel spar was removed to a depth of 200 feet.

In 1945 mining was started from the 250-foot level from the present Main shaft. Even at this depth the fault zone is so deeply weathered that the fluorspar occurs as gravel spar.

\section{JOHN BUTLER}

'The John Butler property contains about 1,700 feet of strike length of faults 2 and 3 , but very little exploration work has been done on it.

\section{EAGLE-CULLEN}

The Eagle-Cullen property covers a total strike length of 5,700 feet on faults 1,2 , and 3 , and about 400 feet on fault $1 B$. Fault 3 has not been prospected on the property, but fault 2 has been opened by a few pits and a shallow shaft and tested with two drill holes. Faults 1 and $1 B$ have been explored rather extensively to a maximum depth of 200 feet. The fluorspar generally was not very wide, and the ore contained large quantities of lead and zinc sulfides that incurred penalties when it was marketed. The assays of bulk samples of some ore are reported to have shown a combined lead and zinc sulfide content of 25 percent.

Some of the earliest prospecting in the Kentucky fluorspar district took place in January 1899 at the Evening Star mine, on what is now the Eagle-Cullen property. Smith (Ulrich and Smith, 1905, p. 195-196) reports that the Evening Star shaft was sunk in the footwall of a fault, here called fault 1 , and 2 drifts were driven southwest, 1 at the 50-foot level for a distance of 25 feet and another at the 89-foot level for a distance of 150 feet. The vein was composed of calcite, fluorspar, and varying quantities of galena and sphalerite. In some places calcite made up the greater part of the vein.

The Joplin shaft (see pl. 11) was sunk in 1900 to a depth of 90 feet on fault $1 B$. Some 500 tons of fluorspar was produced, which contained a total of 10 percent sphalerite and galena. In 1907 an airseparation mill was built, but was not entirely successful in making a. marketable product. The property was idle from 1908 to 1918.

The Eagle Picher Mining and Smelting. Co. drilled 9 holes in 1939 in search of zinc ore. Three holes cut fluorspar rich in sphalerite and galena at depths less than 100 feet. The other 6 holes cut the fault at depths ranging from 100 to 200 feet, but did not disclose ore.

Numerous shallow prospect openings were made between 1918 and 1945, but important fluorspar bodies have not been found. No records of this work are available. The most recent of such tests was made in 1945 by the Eagle Fluor Spar Co. 


\section{GRIMES}

'The Grimes property, owned by Eli Brown of Louisville, Ky., produced approximately 500 tons of fluorspar in 1904. Most of the ore was mined from gravel-spar deposits in the gully north of the present Mosier shaft. The Pope Mining Co. mined about 200 tons of fluorspar in 1910 from an 80-foot shaft sunk in a deeply weathered fault zone about 70 teet east of the Mosier shaft. At approximately the same time the 40-foot Hearne shaft was sunk about 200 feet southwest of the Mosier shaft near the Cullen property line, but the grade of the fluorspar was not very high. Sporadic attempts have been made since then to locate additional fluorspar bodies: Little, if any, of the work has been deep enough to prospect in bedrock. Almost all the attempts have been concentrated along faults 1 and 4 within 500 feet of the southwest property line.

The most recent work on the Grimes property was the sinking of the Mosier shaft in 1944. The shaft is 65 feet deep, and from it a drift has been driven 60 feet S. $25^{\circ}$ E. in what apparently is the weathered clay gouge of a small fault. As this fault was not observed at the surface, it is shown on the map, plate 11, as a possible fault $(1 C)$. 'The Mosier mining operation was abandoned before the end of 1944.

The 6,500 feet of strike length of faults $1,2,3,4,5$, and 6 on the Grimes property is unprospected, other than the 500 feet explored along faults 1 and 4 near the Eagle-Cullen property line.

\section{STEVENS}

About 2,400 feet of strike length of fault 1 crosses the Stevens property, but it has been prospected in only a few pits. The property is controlled by Howard \& Frazer of Marion, Ky.

\section{CARrie BUtLer}

Parts of fault 3 and a total of 2,300 feet of strike length of faults 4 and 7 are on the Carrie Butler property. Very little testing has been done, however.

\section{WRING}

Faults 4, 7, and 9, with a total strike length of 1,900 feet, are on the Wring property. These faults were unprospected before 1947, when the Aluminum Ore Co. started a drilling program there.

\section{EAGLE-LOWERY}

The Eagle-Lowery property, owned by the Eagle Fluor Spar Co. of Salem, Ky., contains a total of 1,000 feet of strike length of faults 1. 7, and 8. A drill hole (U. S. Bureau of Mines diamond-drill hole 73) intersected faults 7 and 8 approximately in the center of the property but failed to disclose fluorspar in minable quantities. No other prospecting has been done. 


\section{EAGIE-WRING}

The Eagle-Wring shaft was sunk by. D. Garth Hearne to a depth of 40 feet in 1924. The shaft was deepened in 1936 by Laurence Hearne to a depth of 170 feet (see pl. 13), and levels were driven at 100, 150, and 170 feet. On the 100 -foot level drifts extended 150 feet northeast and 20 feet southwest partly on top of a fluorspar body. On the 150foot level drifts extended 75 feet northeast and 20 feet southwest, and fluorspar was stoped to the 100-foot level. On the 170-foot level a drift extended 75 feet along the bottom of the ore body. The width of the fluorspar was $11 / 2$ to 8 feet and averaged 4 feet. Approximately 2,500 tons of concentrate produced by $\log$ washing fluorspar from this ore body assayed between 85 and 90 percent calcium fluoride $\left(\mathrm{CaF}_{2}\right)$ and contained a little zinc sulfide $(\mathrm{ZnS})$.

The 430 feet of strike length of fault 7 on the Eagle-Wring property is almost entirely unprospected.

IXIRK

Although faults 3,4 , and 9 have a total strike length of about 5,700 feet on the Kirk property, the property is unprospected.

\section{J. TYNER}

About 600 tons of fluorspar, largely of the gravel-spar variety, has been mined from pits and shafts on fault 1 near the southwest side of the J. Tyner property. Faults $3,4,7$, and 9 have not been tested. The total strike length of these faults on the property is about 2,700 feet.

\section{F. TYNER}

About 2,000 feet of strike length of fault 1 and about 1,000 feet of fault 9 cross the F. Tyner property, controlled by Roberts \& Frazer of Marion, Ky. Fault 9 has not been prospected, but fault 1 has been tested in three shafts and several drill holes to a maximum depth of about 360 feet. The Tyner shaft was sunk in 1924 to a depth of about 100 feet with short drifts at the 60 - and 100-foot levels; the Roberts \& Frazer No. 1 shaft (see pl. 13) was sunk to a depth of 160 feet in 1942; and the Roberts \& Frazer shaft No. 2 is 125 feet deep with about 200 feet of drifts on the 125-foot level. The drifts from the Roberts \& Frazer No. 1 shaft at a depth of 160 feet have a total length of 330 feet. The fault zone generally has been found to contain a vein of calcite, but the fluorspar content has been small.

\section{J. TYNER (ELI BROWN)}

The J. Tyner property, owned by Eli Brown of Louisville; Ky., contains 3,000 feet of strike length of faults 3,4 , and $12 B$ that have not been prospected. This Tyner tract also includes about 1,400 feet of strike length of fault 10 , which is very productive on the Daven- 
port property to the northeast. About 250 feet of strike length of fault 1 crosses the north corner of the property, but the fault is concealed by alluvium and tests have not been made in the area.

The shaft sunk at the junction of faults 10 and $12 B$ is reported. to be about 75 feet deep, but no other information is available.

\section{HICKS (ELI BROWN)}

Fault 1, which has a total strike length of 650 feet on the Hicks (Eli Brown) property, was explored by an 80 -foot shaft sunk in 1930 near the Davenport property line, and about 500 tons of fluorspar. was produced. Some 1,000 feet of strike length on faults 10 and $12 B$ is untested.

\section{DAVENPORT}

The Davenport property was first prospected by a Mr. Arnold in about 1918, but no fluorspar was found. Between 1922 and 1925 contractors operating for the Independent Fluorspar Co., controlled by O. E. Guess and C. W. Haynes, sank a number of shallow shafts and mined a considerable tonnage of fluorspar.

From 1925 to 1930 the Independent Fluorspar Co. was the active operator of the Davenport mine. The Davenport No. 1 shaft was sunk in 1925 to a depth of 150 feet near the northeast corner of the property. Gravel spar was mined to a depth of about 50 feet, and a vein deposit was mined from there to the lowest level. This ore body extended to the northeast onto the Eagle-Watson property and was mined there simultaneously with the mining on the Davenport property. Four other shafts or prospect pits (see pl. 11) were sunk at this same time near the southwestern property line to explore fault 1 to a maximum depth of 170 feet. These four shafts and their workings have remained isolated and are now inaccessible; fluorspar was mined from several stopes, but the quantity is no longer known.

B. E. Clement joined C. W. Haynes in founding the National Fluorspar Co. in 1930. The new company bought the lease on the Davenport property from the Independent Fluorspar Co. and continued the mining operation at the northeast end of the property. Gradually workings were extended southwestward along faults 1,11 , and $11 \mathrm{~A}$, additional shafts were sunk as needed, and the depth of the mine increased to 260 feet (see pl. 14). Fault 11 was mined to a depth of 310 feet from a winze near the crosscut from the Davenport No. 3 shaft. A fissure of small displacement striking almost north intersected fault 11 on the 260 -foot level. The fissure contained a body of fluorspar with an unusually high proportion of sphalerite. In 1942 after the ore was mined, some exploratory crosscutting and core drilling were done eastward from this fissure and fault 10 was discovered. On December 31, 1942, the National Fluorspar Co. exer- 
cised its option to purchase the Davenport property. A.fter development work during 1942 and 1943 had proved the extent of the fluorspar body on fault 10, the Davenport No. 4 shaft was sunk in 1944 to a depth of 310 feet. Some 900 feet of drifts on the 200-, 260-, and 300 -foot levels were driven on fault 10. The fluorspar body exposed was 275 feet long, 165 feet in maximum depth, and ranged in width from 1 foot to 23 feet, averaging 12 feet, according to Clement. In January 1945 the Davenport Mines, Inc., acquired the Davenport property from the National Fluorspar Co.

'The total fluorspar production from the Davenport property is estimated at 60,000 tons.

\section{H. WATSON (ELI BROWN)}

In about 1902 fluorspar was discovered on fault 12 on the H. Watson (Eli Brown) property, but it was not until 1916 that the showing was developed. Between 1916 and 1918 a substantial but unrecorded quantity was mined. The property was idle until 1924, when it was reopened and the workings were greatly enlarged. Locally the mine is known as the Two Brothers mine.

In a wide zone containing several lenticular deposits, gravel spar was mined to a depth of about 250 feet at the Two Brothers mine. In crosscuts on the 240 -foot level (see pl. 14) fluorspar veins $21 / 2-3$ feet thick were found in bedrock along the margins of the fault zone. Apparently the central part of the wide fault zone had been deeply weathered, but the margins still contained the undecomposed vein material. The mining of this mineralized zone is estimated to have yielded about 30,000 tons of fluorspar.

The Kentucky Fluor Spar Co., shaft on this property was sunk by Roberts \& Frazer to a depth of 125 feet. In crosscuts on the 60- and 100 -foot levels the fault was found to contain 3 to 4 feet of mud. The 40 -foot Flannery shaft did not yield fluorspar.

Core drilling of 2 holes by Weitzel in 1942 and 5 holes by the Mahoning Mining Co. in 1945 did not reveal minable fluorspar.

Faults 3 and $12 B$ have a total strike length on the $H$. Watson property of about 3,600 feet but have not been prospected to any great extent. Some 500 feet of strike length of fault 10 has been tested by drilling (see U. S. Bureau of Mines diamond drill holes 7, 8, and 9) in the area where it crosses the $\mathrm{H}$. Watson property between the Eagle-Watson and the Davenport properties. The core holes intersecting the vein at a maximum depth of 425 feet failed to disclose minable bodies of fluorspar. The Batton shaft in this area was sunk in 1942 to a depth of 80 feet but did not reach the fault.

Fault $12 A$ (see pl. 12) has small displacement and is not known to be mineralized. The total strike length of this fault on the $H$. Watson property may be about 500 feet. 
The Eagle-Watson property, owned by the Eagle Fluor Spar Co., was explored first in 1918. The extensive deposits of gravel spar in the southwestern part of the property were the first to be developed. The overburden in this area, found at depths as great as 120 feet, contained many high-grade pockets and lenses of fluorspar that apparently were derived from a network of small faults and other fissures subsidiary to fault 1 . Bedrock is not exposed in this area. Fluorspar was produced from workings ranging in depth from 20 to 70 feet. Simple log washing of the ore generally yielded a metallurgical-grade sand; lump acid-grade fluorspar was obtained by hand sorting of the large material.

The unusual extent of deposits of gravel spar near fault 1 in this area may be explained as follows: The Salem fault, where known several miles to the southwest, strikes toward the Moore. Hill fault system; its projection would intersect the system in the vicinity of the Eagle-Watson property. The network of faults and the wide brecciated zone, which was found to be several hundred feet thick in U. S. Bureau of Mines diamond drill hole 12, may be located on this property at the intersection of these two faults. Mineralization along the many fissures in this disturbed area resulted in numerous veins and lenses of fluorspar, which upon subsequent weathering formed the extensive deposits of gravel spar.

Deeper mining has been done along the full strike length of fault 1 on the property (see pl. 15). Veins in bedrock have been mined in this area by means of the 300 -foot Main shaft, now caved around the collar, the 260-foot No. 2 shaft, the 250-foot Red Headframe shaft, and some smaller shafts. The Main shaft was sunk close to a lamprophyre dike that was not exposed at the surface. A small quantity of fluorspar was found in a fault zone near the dike. Workings from the Main shaft were most extensive between the 200-foot level and the surface. The shaft was deepened to 300 feet and drifts were driven on the vein, but the fluorspar content was too low for the vein to be mined. The Red Headframe shaft was bottomed at a depth of 250 feet in wet sand, probably part of an active watercourse, which could be worked only with great difficulty. Stoping operations have been continuous from the 200-foot level to the surface. Three drill holes cut the faults below the workings from these three shafts without disclosing minable bodies of fluorspar.

The Green Headframe shaft was sunk in the hanging wall of fault 10 , which dips $55^{\circ} \mathrm{NW}$. The shaft crossed the fault at a depth of 115 feet and continued in the footwall to a depth of 260 feet. A considerable quantity of ore was mined from scattered stopes on fault 10, but on the Eagle-Watson property the fault does not contain a large con- 
tinuous fluorspar body such as it does on the Davenport property to the southwest.

A few pits and the Eagle-Watson shaft were sunk on fault 12 on the hill south of the Main shaft. These openings prospected the northeast extension of the structures that carry ore bodies worked at the Two Brothers mine on the H. Watson (Eli Brown) property. The EagleWatson shaft (see pl. 14) is 180 feet deep and has exploratory workings at the lowest level, but only a small tonnage of fluorspar was found. In 1944 a core hole was drilled from the bottom of the shaft. The core hole, 400 feet long, cut fault $12 A$, but no fluorspar was found. In 1945,130 feet of additional drifting failed to locate minable fluorspar.

The production of fluorspar from the Eagle-Watson property is estimated at 100,000 tons. Since 1943, contractors produced small tonnages of fluorspar from shallow workings in the gravel-spar deposits on the Eagle-Watson property while the Eagle Fluor Spar Co. developed properties along other fault systems in the district.

\section{TIGHTWAD (L. E. WADDELL)}

Although the Tightwad (L. E. Waddell) property is a large tract, only a wedge-shaped part on the southeast side covers any part of the Moore Hill fault system. About 300 feet of strike length of fault 12 is unexplored; the 400-foot section along fault 1, however, has been worked extensively for gravel spar. Some mining of fluorspar veins in bedrock has been done, but the tonnage produced is not recorded. The maximum depth of exploration is about 150 feet.

Between 1934 and 1940 John Summers, contractor for Denny \& Likens, is reported to have mined about 6,000 tons of fluorspar from workings near the bottom of the creek. In 1945 Roberts began reexploring this part of the property; an old 130 -foot shaft was repaired, and some drifts and winzes were made on the bottom level.

In about 1941 Denny \& Likens sank a 140-foot shaft (see pl. 16) near the Eagle-Watson property line and mined fluorspar from the extension of a deposit of gravel spar mined on the Eagle-Watson property. About 40 feet southeast of this shaft, a new shaft was sunk in the limestone hanging wall to a depth of 120 feet. In July 1943 Conyer $\&$ Crider, subleasing from Denny \& Likens, drove a crosscut to the fault from the new shaft but found that the deposit of gravel spar had been depleted.

\section{LUDWIG}

Faults 1, 3, and 12 have a total strike length of 2,100 feet on the Ludwig property. The 1,000-foot length of fault 3 is unprospected. Fault 1 was prospected to a maximum depth of 310 feet by two drill holes. The fault zone was wide and had been mineralized, but not 
in commercial quantities at any of the places intersected, even though hole 47 cut fault 1 in the broad intensely brecciated zone marking its junction with fault 12 .

\section{MCCUNE}

More than 1,000 feet of strike length of fault 3 crosses the McCune property and is untested. Both ends of the 675 feet of strike length of fault 1 have been prospected. In 1926 the Stewart Spar Co. sank the shaft at the northeast end to a depth of 97 feet. Short crosscuts and levels were driven at depths of 42 and 97 feet. The upper level cut small pockets of gravel spar; from the lower level about 5 tons of highgrade fluorspar was mined, but the body soon was exhausted. At the same time a 48-foot shaft was sunk near the Ludwig property line to the southwest. A crosscut was driven 10 feet to the vein; about 10 tons of fluorspar was mined, but the operation was abandoned.

In 1943 the New York and Kentucky Fluorspar Co. retimbered and deepened to 120 feet the shaft at the southwest end of fault 1, drove a crosscut 50 feet, and drifted 65 feet to the northeast (see pl. 16). Fluorspar is present as stringers and disseminations throughout the 40-foot width of the fault zone, but no commercial bodies were found. Prospecting ceased in 1943, and the lease was taken over by Perry \& Loyd of Marion, $\mathrm{Ky}$.

\section{OXIEY}

The Oxley property, controlled by Roberts \& Frazer of Marion, Ky., was explored extensively first in 1917. The Oxley shaft was sunk in the hanging wall of fault 1 to a depth of 100 feet. Crosscuts were driven to the southeast and northwest in search of the fault, which was located in the northwest crosscut at a distance of about 80 feet from the shaft. Because little minable fluorspar was located in short drifts along the fault, the work ceased. North of the Oxley shaft two shafts (see pl. 12) were sunk in 1929 about 150 feet apart, the southernmost to a depth of 115 feet and the northernmost to a depth of 50 feet. From the 50-foot shaft approximately 125 feet of drifting was done on the 25 -foot level and about 50 feet on the 50 -foot level. From the 115-foot shaft a crosscut on the 90 -foot level intersected the old drift from the Oxley shaft. This old level was continued a short distance to the northeast where an inclined raise was driven to meet the 25-foot level from the other shaft. From all accounts it would seem that the Oxley shaft and the 115-foot shaft explored fault 1 in bedrock, but that the 50 -foot shaft was entirely in overburden. The workings in bedrock are not recorded as having yielded any ore, but stoping between the 50- and 25-foot levels of the shallow shaft produced considerable gravel spar. 
In 1939 the Pepperbox No: 1 shaft was sunk to a depth of 185 feet on the Oxley property. Workings along the fault zone at that depth exposed soft, highly decomposed material but no deposits of gravel spar. Drill hole 61 put down by the U. S. Bureau of Mines intersected the fault zone almost 100 feet below the lowest workings but failed to reveal a commercial body of fluorspar.

\section{SUMMERS AND CONYER}

The Summers mine is located on the Summers and Conyer properties: E. K. Summers first prospected this area in 1923, and R. J. Forester acquired the properties in 1925. At that time the main shaft was 150 feet deep with levels at depths of 70 and 150 feet. To the southwest near the Oxley property line several pits and three small shafts had also been sunk, but in none was minable fluorspar found. For a few months in 1926 the Stewart Spar Co. operated the mine under lease from Forester and produced about 500 tons of fluorspar.

In 1929 the mill was erected but after a trial run was shut down until 1933. The property has been active only intermittently since then. The production has totalled about 15,000 tons of metallurgicalgrade fluorspar.

The shaft at the Summers mine is now 250 feet deep, and all workings above the 250 -foot level have been abandoned. For a short time in February 1943 the northeast end of the 200-foot level was accessible through a raise from the 250 -foot level. A 310 -foot level has been driven and worked from a winze on the southwest drift of the 250-foot level. (See pl. 17.)

\section{WATSON}

The part of the Watson property adjoining the Oxley property on the east is crossed by about 800 feet of strike length of fault 3 , but no prospecting has been done. An untested strike length of 1,800 feet of the same fault crosses the part of the Watson property that lies northeast of the Conyer property.

\section{LA RUE (R, J, FORESTER)}

The main structure crossing the La Rue (R. J. Forester) property is fault 1, with a strike length of about 1,400 feet. Fault 1 has been tested by five drill holes to a maximum depth of 320 feet. Where intersected, the fault zone contained small quantities of fluorspar. This property also includes about 200 feet of the projection of fault 15 (Eaton fault), but this section of the fault has not been prospected.

\section{A. TINSLEY}

The A. Tinsley property contains fault 15 (Eaton fault) but none of the main structures of the Moore Hill fault system. Fault 15 is a 
cross fault of small displacement that extends from fault 1 of the Moore Hill fault system to the southeastern bounding fault of the Levias-Crittenden Spring fault system. Shallow workings have yielded small tonnages of gravel spar on the A. Tinsley property.

\section{SISCO}

The part of the Sisco property included in the present mapping contains a total of approximately 3,300 feet of strike length along faults 1,3 , and 14. Fault 3 has been tested to a maximum depth of 200 feet by a few shallow pits, a vertical drill hole, and an inclined drill hole, but no fluorspar was found.

\section{LA RUE (RIGGS)}

The La Rue (Riggs) property located northwest of the Sisco property contains parts of faults 15 and 16 . Fault 16, known also as the Dike fault because of the presence of a lamprophyre dike along its course, is a cross fault between the Moore Hill fault system and the Levias-Crittenden Spring fault system. The Riggs shaft near Dry Creek is the southeasternmost opening on fault 16. The workings from this shaft have a maximum depth of 145 feet (see pl. 16).

\section{LITERATURE CITED}

Currier, L. W., 1923, Fluorspar deposits of Kentucky: Ky. Geol. Survey, ser. 6, v. 13.

Fohs, F. J., 1905, Clays in Crittenden and Livingston Counties, Ky.: Ky. Geol. Survey Bull. 6.

Pye, W. D., 1944, Petrology of the Bethel sandstone of south-central Illinois: Am. Assoc. Petroleum Geologists Bull., v. 28, p. 63-122.

Starnes, X. B., 1946, Moore Hill fault vein, Crittenden and Livingston Counties, Ky., in Starnes, X. B., and Hickman, R. C., Exploration for fluorite, Crittenden and Livingston Counties: U. S. Bur. Mines Rept. Invest. 3943, pt. 1.

Ulrich, E. O., and Smith, W. S. T., 1905, Lead, zinc, and fluorspar deposits of western Kentucky: U. S. Geol. Survey Prof. Paper 36.

Weller, Stuart, 1920, Geology of Hardin County, Illinois : Ill. Geol. Survey Bull. 41.

Weller, Stuart, 1927, Geology of the Cave in Rock quadrangle: Ky. Geol. Survey, ser, 6, v. 26.

Weller, Stuart, and Sutton, A. H., 1951, Geologic map of the western Kentucky fluorspar district: U. S. Geol. Survey Min. Invest. Field Studies no. 2. 



\section{INDEX}

\begin{tabular}{|c|c|}
\hline Page & Page \\
\hline Abstract. & Kirk property \\
\hline cknowledgments.. & \\
\hline American Lead, Zinc and $\mathrm{T}$ & 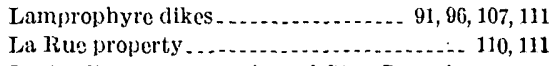 \\
\hline Bennett property ... & Levias limestone member of Ste. Genevieve \\
\hline 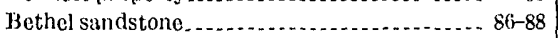 & limestone.................. \\
\hline Brown, Eli, property of ....... & Literature cited. . . . . . \\
\hline Bureau of Mines, drill holes & $\begin{array}{l}\text { Location of the area } \ldots \ldots \ldots \ldots \ldots \ldots \ldots \ldots \\
\text { Ludwig property } \ldots \ldots \ldots \ldots \ldots \ldots \ldots\end{array}$ \\
\hline alcite.................... & \\
\hline Carrie Butler property .... & McCune property...- \\
\hline Chester group.................... & Mahoning Mining $\mathrm{C}_{0} \ldots \ldots$ \\
\hline Cypress sandstone.... & $\begin{array}{l}\text { Meramec group, rocks of } \ldots \ldots \ldots \\
\text { Midlunds Mineral Corp } \ldots \ldots\end{array}$ \\
\hline Davenport Mines Inc.. & Milling the ore........................... 90-100 \\
\hline Davenport property & Mineral constituents, of Bethel sandstonc .... $87-88$ \\
\hline Dikes, description of. & 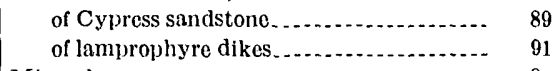 \\
\hline Eagle.Cullen property..... & (n) \\
\hline Spar Co & 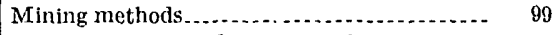 \\
\hline property & Mining properties, description of . ......... 100-111 \\
\hline ng and Smelting Co...... 102 & Moore Hill fault system, description of . ...... $91-96$ \\
\hline $107-108$ & source of name........ \\
\hline ... 104 & \\
\hline ies of the area..... & ty \\
\hline . . $91-96$ & New York and Kentucky Fluorspar Co..... 109 \\
\hline Field work ........... & \\
\hline Fire-clay deposit............. & oxley property ...................... \\
\hline Fluorite & \\
\hline Fluorspar deposits, origin . . ........ & Paint \\
\hline 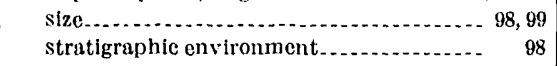 & Pope Mining Co ....... \\
\hline nt of $\ldots \ldots \ldots$ & 86 \\
\hline Forester, R. J., property of...... 110 & rty ......... \\
\hline Fossils $\ldots \ldots \ldots \ldots$ & Roberts \& Frazer. \\
\hline Ste. Genevieve & Rosiclare sandstone member of Ste. Genevieve \\
\hline $84-8.5$ & \\
\hline a & \\
\hline - $84-96$ & Ste. Genevieve limestone............ \\
\hline Golco & Sedimentary rocks, description...... \\
\hline Gravel-spar deposits, size... & Sisco property ........................ \\
\hline Grimes property.... & \\
\hline _..... 84-96 & Stevens property.. \\
\hline Hardinshurg sandstonc..................... $90-91$ & Stewart Spar Go \\
\hline Hicks property..... & $\begin{array}{l}\text { Stratigraphic section } \\
\text { Structure............ } 84\end{array}$ \\
\hline and & and Conyer property .................... \\
\hline lorspar Co............... 105 & \\
\hline ........ $81-83$ & $\begin{array}{l}\text { Teer property } \\
\text { Thurston, W. R., Fluorspar deposits....... 96-111 }\end{array}$ \\
\hline hint & $\begin{array}{l}\text { Tightwad property } \\
\text { Tinsley, A., property }\end{array}$ \\
\hline & er, J., property .... \\
\hline
\end{tabular}

